\title{
Water table effects on measured and simulated fluxes in weighing lysimeters for differently-textured soils
}

\author{
Martin Wegehenkel ${ }^{1 *}$, Horst H. Gerke ${ }^{2}$ \\ ${ }^{1}$ Institute of Landscape Systems Analysis, Leibniz-Centre for Agricultural Landscape Research (ZALF) Müncheberg, Eberswalder Strasse \\ 84, D-15374 Müncheberg, Germany. \\ ${ }^{2}$ Institute of Soil Landscape Research, Leibniz-Centre for Agricultural Landscape Research (ZALF) Müncheberg, Germany. \\ Tel.: +4933432 / 82229. Fax:+4933432 /82280. Email: hgerke@zalf.de \\ ${ }^{*}$ Corresponding author. Tel.: +49 33432 / 82275. Fax: +4933432 / 82334. Email: mwegehenkel@zalf.de
}

\begin{abstract}
Weighing lysimeters can be used for studying the soil water balance and to analyse evapotranspiration (ET). However, not clear was the impact of the bottom boundary condition on lysimeter results and soil water movement. The objective was to analyse bottom boundary effects on the soil water balance. This analysis was carried out for lysimeters filled with fine- and coarse-textured soil monoliths by comparing simulated and measured data for lysimeters with a higher and a lower water table. The eight weighable lysimeters had a $1 \mathrm{~m}^{2}$ grass-covered surface and a depth of $1.5 \mathrm{~m}$. The lysimeters contained four intact monoliths extracted from a sandy soil and four from a soil with a silty-clay texture. For two lysimeters of each soil, constant water tables were imposed at $135 \mathrm{~cm}$ and $210 \mathrm{~cm}$ depths. Evapotranspiration, change in soil water storage, and groundwater recharge were simulated for a 3-year period (1996 to 1998) using the Hydrus-1D software. Input data consisted of measured weather data and crop model-based simulated evaporation and transpiration. Snow cover and heat transport were simulated based on measured soil temperatures. Soil hydraulic parameter sets were estimated (i) from soil core data and (ii) based on texture data using ROSETTA pedotransfer approach. Simulated and measured outflow rates from the sandy soil matched for both parameter sets. For the sand lysimeters with the higher water table, only fast peak flow events observed on May 4, 1996 were not simulated adequately mainly because of differences between simulated and measured soil water storage caused by ET-induced soil water storage depletion. For the silty-clay soil, the simulations using the soil hydraulic parameters from retention data (i) were matching the lysimeter data except for the observed peak flows on May, 4, 1996, which here probably resulted from preferential flow. The higher water table at the lysimeter bottom resulted in higher drainage in comparison with the lysimeters with the lower water table. This increase was smaller for the finer-textured soil as compared to the coarser soil.
\end{abstract}

Keywords: Weighable lysimeters; Modelling; Hydrus-1D; Drainage; Boundary condition.

\section{INTRODUCTION}

Weighable lysimeters have been developed for the experimental determination of the components of the water balance such as evapotranspiration (ET), change in soil water storage, and groundwater recharge under naturally-varying atmospheric boundary conditions (e.g., Loos et al., 2007). Therefore, lysimeter data have frequently been used for testing soil water balance models (e.g., Abdou and Flury, 2004; Herbst et al., 2005; Kasteel et al., 2007) and for the optimization of soil hydraulic parameters (e.g., Durner et al., 2008; Kelleners et al., 2005; Schelle et al., 2012). Despite the recent progress in lysimeter techniques (e.g., von Unold and Fank, 2008), some mismatch between model output and lysimeter data remained unexplained. Oasis effects, impact of wind pressure and snow cover on lysimeter mass changes, and preferential flow along lysimeter walls have been reported as error sources (e.g., Corwin, 2000; Selle et al., 2011). Minimization of such errors could be achieved by the use of relatively undisturbed, intact soil monoliths, more accurate and continuous weighing systems, and highly-controlled bottom boundary conditions; and by providing relatively identical surface properties or vegetation structures in the area surrounding the lysimeter. Furthermore, the bottom boundary conditions were found to affect lysimeter drainage rates (e.g., Kasteel et al., 2007; Mertens et al., 2005a).

In a previous study (Wegehenkel et al., 2008), drainage rates measured by grass covered weighing lysimeters were underestimated by a simplified soil water balance model. Mismatch between simulated and measured lysimeter drainage was explained by Loos et al. (2007), Mertens et al. (2005b), and Kelleners et al. (2005), among others, with inaccurate parameterization of soil hydraulic properties and the use of an inappropriate ET model. In order to explain the underestimation of simulated drainage, a more sophisticated ET model was tested that included a physiologically-based vegetation growth model (Wegehenkel and Gerke, 2013). Still, some observed percolation events and cumulative drainage rates could not adequately be simulated despite an improved description of actual evapotranspiration (ETa) rates. The results suggested that a more physically-based water flow model together with improved data of soil hydraulic properties is required to properly account for soil water movement under imposed boundary conditions.

The objective of the present study was to analyse the impact of higher and lower water tables as the bottom boundary condition on the soil water balance of a coarser- in comparison to a finer-textured soil. The analysis was carried out with a widely-used physically-based water flow model HYDRUS that numerically solves the Richards equation. Simulations results obtained with two different soil hydraulic parameter sets were compared with measured data and most critical periods were identified. 
Table 1. Soil physical and hydraulic properties for the soil horizons of the lysimeter soils (Diestel et al., 2007; modified); texture classes: sand $(2.0-0.063 \mathrm{~mm})$, silt $(0.063-0.002 \mathrm{~mm})$, and clay $(<0.002 \mathrm{~mm})$; SOM: soil organic matter; $\mathrm{pF}$ is $\log (|h|)$ with $h$ the soil water pressure head in $\mathrm{cm}$.

\begin{tabular}{|c|c|c|c|c|c|c|c|c|c|}
\hline \multicolumn{10}{|c|}{ a) Lysimeters 1-4, HaplicPodzol (FAO) } \\
\hline \multicolumn{6}{|c|}{$\begin{array}{l}\text { Lysimeters } 1 \text { and } 2 \text {, } \\
\text { water table at } 210 \mathrm{~cm} \text { depth }\end{array}$} & \multicolumn{4}{|c|}{$\begin{array}{l}\text { Lysimeters } 3 \text { and } 4 \text {, } \\
\text { water table at } 135 \mathrm{~cm} \text { depth }\end{array}$} \\
\hline \multirow[t]{2}{*}{ Horizon } & \multirow{2}{*}{$\begin{array}{l}\text { Depth } \\
(\mathrm{cm})\end{array}$} & \multirow{2}{*}{$\begin{array}{l}\text { Sand } \\
(\%)\end{array}$} & \multirow{2}{*}{$\begin{array}{l}\text { Silt } \\
(\%)\end{array}$} & \multirow{2}{*}{$\begin{array}{l}\text { Clay } \\
(\%)\end{array}$} & \multirow{2}{*}{$\begin{array}{l}\text { SOM } \\
(\%)\end{array}$} & Porosity & \multicolumn{3}{|c|}{ Volumetric water content at $\mathrm{pF}$} \\
\hline & & & & & & $\left(\mathrm{cm}^{3} \mathrm{~cm}^{-3}\right)$ & $1.8\left(\mathrm{~cm}^{3} \mathrm{~cm}^{-3}\right)$ & $2.5\left(\mathrm{~cm}^{3} \mathrm{~cm}^{-3}\right)$ & $4.2\left(\mathrm{~cm}^{3} \mathrm{~cm}^{-3}\right)$ \\
\hline Ap & $0-40$ & 81 & 15 & 4 & 4.0 & 0.427 & 0.230 & 0.165 & 0.050 \\
\hline Bsh1 & $40-60$ & 80 & 15 & 5 & 1.3 & 0.386 & 0.168 & 0.107 & 0.023 \\
\hline Bsh2 & $60-150$ & 87 & 9 & 4 & 0.5 & 0.363 & 0.253 & 0.166 & 0.043 \\
\hline \multicolumn{10}{|c|}{ b) Lysimeters 9-12, EutricCambisol (FAO) } \\
\hline \multicolumn{6}{|c|}{$\begin{array}{l}\text { Lysimeters } 9 \text { and } 10 \text {, } \\
\text { water table at } 135 \mathrm{~cm} \text { depth }\end{array}$} & \multicolumn{4}{|c|}{$\begin{array}{l}\text { Lysimeters } 11-12, \\
\text { water table at } 210 \mathrm{~cm} \text { depth }\end{array}$} \\
\hline Ap & $0-20$ & 4 & 67 & 29 & 2.8 & 0.360 & 0.345 & 0.340 & 0.215 \\
\hline Bv1 & $20-60$ & 4 & 69 & 27 & 1.0 & 0.420 & 0.352 & 0.337 & 0.197 \\
\hline Bv2 & $60-150$ & 6 & 75 & 19 & 0.4 & 0.350 & 0.325 & 0.305 & 0.155 \\
\hline
\end{tabular}

\section{MATERIALS AND METHODS}

\section{Test site}

The weighable lysimeters and an agrometeorological field station were both located in Berlin-Dahlem, Germany, at $52^{\circ} 28^{\prime} \mathrm{N}$ and $13^{\circ} 18^{\prime} \mathrm{E}$, and at an elevation of $51 \mathrm{~m}$ a.s.l. These lysimeters were operated from 1990 to 2004 by the former Department of Applied Hydrology, Resource Protection, Irrigation, and Drainage of the Technical University of Berlin, Germany (e.g., Diestel et al., 2007). In four lysimeters (1-4), each with a diameter of $112 \mathrm{~cm}$ and a depth of $150 \mathrm{~cm}$, undisturbed soil monoliths extracted from a sandy site and in four other lysimeters (9-12), soil monoliths from a silty-clay site were fitted; basic soil properties are summarized in Table 1. These lysimeters were installed on even level with the ground surface and placed on a weighing system (Diestel et al., 2007). This system measured lysimeter mass changes with a sensitivity of $100 \mathrm{~g}(\approx 0.1 \mathrm{~mm}$ of water); a second separate weighing system with a sensitivity of $5 \mathrm{~g}$ measured drainage or water uptake (e.g., by capillary rise) at the bottom from a reservoir. For lysimeters 3-4 and 9-10, the groundwater level was kept constant at $135 \mathrm{~cm}$ depth. For the lysimeters 1-2 and 11-12, the groundwater level was kept at $210 \mathrm{~cm}$ depth. The lysimeter mass changes were monitored electronically in intervals of 15 min. Precipitation, air and soil temperatures, air humidity, wind speed, global radiation, diffuse radiation, and net radiation were registered at the agrometeorological field station every $1 \mathrm{~min}$ and combined to obtain 15-min averages. Daily sums and averages were obtained from the 15 -min data.

The lysimeter data used in the present study consist of daily rates of actual evapotranspiration (ETa), daily changes in soil water storage (i.e., determined from lysimeter mass changes), daily drainage rates, and meteorological data. This data set covers the time period from January 1, 1996 up to December 31,1998 . The highest daily precipitation rates were $56 \mathrm{~mm} \mathrm{~d}^{-1}$, observed on May 3, 1996 and $41 \mathrm{~mm} \mathrm{~d}^{-1}$ measured on August 14, 1996 and of $46 \mathrm{~mm} \mathrm{~d}^{-1}$, observed on July 20, 1997. At all lysimeters, perennial grass (Lolium Perenne L.) vegetation was established (Diestel et al., 2007).

\section{Simulation model Hydrus-1D}

Variably-saturated water flow in the Hydrus-1D code (Simunek et al., 2008) is described with the Richards equation: $\frac{\partial \theta}{\partial t}=\frac{\partial}{\partial z}\left[K\left(\frac{\partial h}{\partial z}+1\right)\right]-S$

Here, $\theta$ is the volumetric water content in $\mathrm{L}^{3} \mathrm{~L}^{-3}, t$ is time $(\mathrm{T}), \mathrm{z}$ is the spatial coordinate (L, positive upwards), $K$ is the unsaturated hydraulic conductivity $\left(\mathrm{L} \mathrm{T}^{-1}\right)$ as a function of the soil water pressure head, $h(\mathrm{~L})$, and $S$ is a sink term $\left(\mathrm{T}^{-1}\right)$ to account for water uptake by plant roots. Root water uptake was calculated according to Feddes et al. (1978):

$S(h)=\beta(h) S_{p}$

where the root-water uptake stress response function $\beta(h)$ is a dimensionless function of the soil water pressure head with a range $0 \leq \beta \leq 1$, and $\mathrm{S}_{\mathrm{p}}$ is the potential root water uptake rate $\left(\mathrm{T}^{-1}\right)$. The stress response function $\beta(h)$ is defined as follows:

$\beta(h)=\frac{h-h_{4}}{h_{3}-h_{4}}$ for $h_{4}<h \leq h_{3}$

$\beta(h)=1$ for $h_{3}<h \leq h_{2}$

$\beta(h)=\frac{h-h_{1}}{h_{2}-h_{1}} \quad$ for $\quad h_{2}<h \leq h_{1}$

$\beta(h)=0 \quad$ for $h \leq h_{4}$ and $h>h_{1}$

where $h_{l}, h_{2}, h_{3}$, and $h_{4}$ are crop-specific threshold parameters (Simunek et al., 2008). In Eq. (3), root water uptake is at the potential rate when the pressure head, $h$, is between $h_{2}$ and $h_{3}$; uptake decreases linearly for $h_{2}<h<h_{3}$ and becomes zero for $h$ $\leq h_{4}$ or $h>h_{l}$. The spatial distribution of $S_{p}$ over the root zone is described as

$S_{p}=b(x) T_{p o t}$

where $b(x)$ is the normalized root water uptake distribution $\left(\mathrm{L}^{-1}\right)$ and $T_{p o t}$ is potential transpiration $\left(\mathrm{L} \mathrm{T}^{-1}\right)$.

At the soil surface, an atmospheric boundary condition is imposed as defined in the Hydrus code. This condition switches 
between a defined infiltration or evaporation flux and a defined pressure head depending on the actual value of the pressure head at the soil surface. For the surface pressure head, $h(0, t)$, within limits $\left(h_{a}<h(0, t)<h_{s}\right)$, a flux condition is defined as:

$$
\left|-K(h) \frac{\partial h}{\partial z}-K(h)\right|=R
$$

Here, $R$ is potential infiltration or evaporation rate $\left(\mathrm{L} \mathrm{T}^{-1}\right)$ and $h_{a}$ and $h_{s}$ are minimum and maximum values of the pressure head. The default values of $h_{a}=-10^{6} \mathrm{~cm}$ and $h_{s}=0 \mathrm{~cm}$ are used. In the Hydrus-1D code, snow accumulation is calculated when the air temperature is below $-2^{0} \mathrm{C}$. When the air temperature is above zero, the existing snow layer melts proportional to the air temperature using a snow melting constant. Simulation of snow cover dynamics in Hydrus-1D is connected to the calculation of heat transfer, which is described with a convection-dispersion equation. More details can be obtained from Simunek et al. (2008).

The soil hydraulic functions are described according to van Genuchten (1980) and Mualem (1976):

$$
\begin{aligned}
& K(h)=\frac{K_{\text {sat }}\left(1-(\alpha|h|)^{n-1}\left[1+(\alpha|h|)^{n}\right]^{-m}\right)^{2}}{\left(1+(\alpha|h|)^{n}\right)^{\frac{m}{2}}}, \text { and } \\
& \theta(h)=\theta_{r}+\frac{\theta_{s}-\theta_{r}}{\left(1+(\alpha|h|)^{n}\right)^{m}}
\end{aligned}
$$

where $K_{\text {sat }}$ is the hydraulic conductivity at water saturation $\left(\mathrm{L} \mathrm{T}^{-1}\right)$, $\alpha\left(\mathrm{L}^{-1}\right)$ and $\mathrm{n}$ (dimensionless) are soil-specific parameters; $\theta_{s}$ is the saturated and $\theta_{r}$ the residual soil water content parameter $\left(\mathrm{L}^{3} \mathrm{~L}^{-3}\right)$, and $m=1-1 / n$. In the Hydrus-1D program, Eq. (1) is solved numerically using Galerkin-type linear finite element schemes; integration in time is achieved using an implicit (backwards) finite difference scheme for both saturated and unsaturated conditions (Simunek et al., 2008).

\section{Model set up}

Hydrus-1D simulations were carried out for the period January 1, 1996 to December 31, 1998 for each lysimeter. The soil profiles of the lysimeters were spatially discretized in 150 computational layers of $1 \mathrm{~cm}$ thickness. The atmospheric boundary condition for the model application was defined by measured daily rates of rainfall; transpiration $(\mathrm{T})$ and evaporation $(\mathrm{E})$ rates of the grass cover were obtained from a physiologically-based grass cover growth model (Wegehenkel and Gerke, 2013). The ETa-rate time-series obtained from the lysimeter data directly could not be used here for the simulations because of important data gaps (c.f., Wegehenkel and Gerke, 2013). An example of the input data for lysimeters 1-2 is presented in Fig. 1. Soil temperatures below $0^{\circ} \mathrm{C}$ measured in 10 and $30 \mathrm{~cm}$ depths were rare; frozen soil conditions could only be observed between January and March 1996. In the other winter periods, soil temperatures were mainly above $0^{\circ} \mathrm{C}$ (Fig. 1).

To account for the winter periods, snow cover accumulation, snow melt, and heat transport were simulated by using measured soil temperatures at soil surface, and at $10 \mathrm{~cm}, 20 \mathrm{~cm}$, and $30 \mathrm{~cm}$ depth. The snow melting constant as one input for snow cover modeling was set at $0.43 \mathrm{~cm}$; for the estimation of soil thermal conductivity $\lambda(\theta)\left(\mathrm{M} \mathrm{L} \mathrm{T}^{-3} \mathrm{~K}^{-1}\right)$, we used Chung and Horton-approach (Chung and Horton, 1987) defined as follows

$$
\lambda(\theta)=b_{1}+b_{2} \theta+b_{3} \theta^{0.5}
$$

We used the following values of the empirical parameters $b_{1}-b_{3}: b_{1}=0.228, b_{2}=-2.406$ and $b_{3}=4.909 \mathrm{~W} \mathrm{~m}^{-1} \mathrm{~K}^{-1}$ for the sand lysimeters $1-4$ and $b_{1}=0.243, b_{2}=0.393$ and $b_{3}=1.534 \mathrm{~W}$ $\mathrm{m}^{-1} \mathrm{~K}^{-1}$ for loam lysimeters 9-12 (Chung and Horton, 1987).
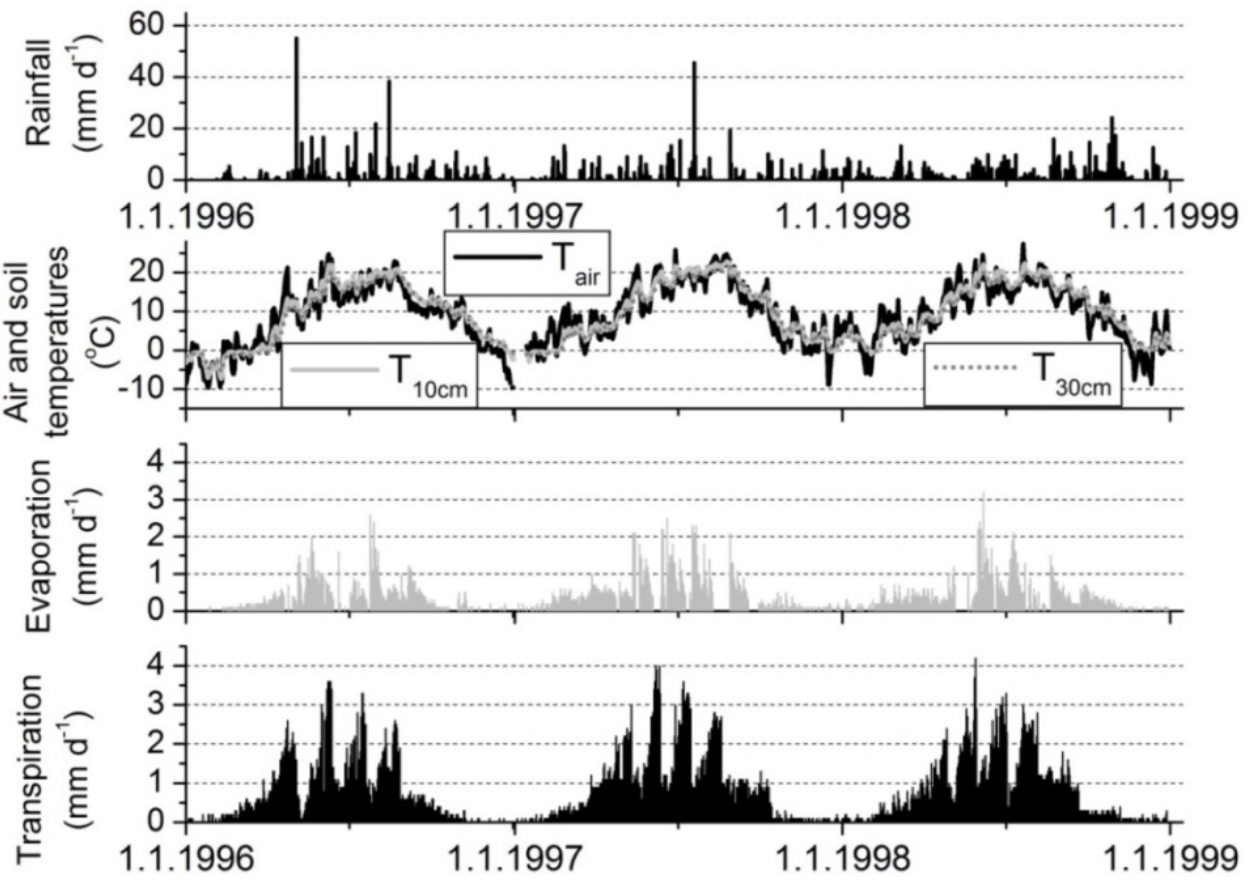

Fig. 1. Observed rainfall $\left(\mathrm{mm} \mathrm{d}^{-1}\right)$, air temperature $\left(T_{\text {air }}\right)$, soil temperature at $10 \mathrm{~cm}$ and $30 \mathrm{~cm}$ depth $\left(T_{10 \mathrm{~cm}}, T_{30 \mathrm{~cm}}\right)$ in ${ }^{0} \mathrm{C}$, simulated evaporation and transpiration for the lysimeters $1-2$ in $\mathrm{mm} \mathrm{d}^{-1}$. 
Table 2. First set of the soil hydraulic van Genuchten-Mualem-parameters $\theta_{s}, \theta_{r}, \alpha, n$, estimated by the program RETC (van Genuchten et al., 1991) using $\mathrm{pF}$-data from Table 1 , and estimates of the saturated hydraulic conductivity $K_{\text {sat }}$ obtained from tabular data (AG Boden, 2005).

\begin{tabular}{llllll}
\hline \multicolumn{2}{l}{ a) Lysimeters $1-4$} & & & \\
\hline Horizon & $\theta_{s}\left(\mathrm{~cm}^{3} \mathrm{~cm}^{-3}\right)$ & $\theta_{r}\left(\mathrm{~cm}^{3} \mathrm{~cm}^{-3}\right)$ & $\alpha\left(\mathrm{cm}^{-1}\right)$ & $n$ & $K_{\text {sat }}\left(\mathrm{cm} \mathrm{d}^{-1}\right)$ \\
\hline Ap & 0.427 & 0.046 & 0.053 & 1.516 & 140 \\
Bsh1 & 0.401 & 0.025 & 0.052 & 1.667 & 221 \\
Bsh2 & 0.366 & 0.01 & 0.028 & 1.401 & 49 \\
\hline b) Lysimeters $9-12$ & & & & \\
\hline Ap & 0.360 & 0.15 & 0.004 & 1.112 & 25 \\
Bv1 & 0.420 & 0.17 & 0.025 & 1.425 & 3 \\
Bv2 & 0.350 & 0.13 & 0.004 & 1.172 & 1 \\
\hline
\end{tabular}

Table 3. Second set of the soil hydraulic van Genuchten-Mualem-parameters $\theta_{s}, \theta_{r}, \alpha, n$, and values of the saturated hydraulic conductivity $K_{\text {sat }}$ obtained from pedotransfer functions using the program ROSETTA.

\begin{tabular}{llllll}
\hline \multicolumn{2}{l}{ a) Lysimeters 1-4 } & & & \\
\hline Horizon & $\theta_{s}\left(\mathrm{~cm}^{3} \mathrm{~cm}^{-3}\right)$ & $\theta_{r}\left(\mathrm{~cm}^{3} \mathrm{~cm}^{-3}\right)$ & $\alpha\left(\mathrm{cm}^{-1}\right)$ & $n$ & $K_{\text {sat }}\left(\mathrm{cm} \mathrm{d}^{-1}\right)$ \\
\hline Ap & 0.409 & 0.041 & 0.049 & 1.800 & 184 \\
Bsh1 & 0.409 & 0.041 & 0.041 & 1.790 & 123 \\
Bsh2 & 0.387 & 0.046 & 0.037 & 2.310 & 262 \\
\hline b) Lysimeters 9-12 & & & & 1.550 \\
\hline Ap & 0.458 & 0.085 & 0.007 & 1.570 & 7 \\
Bv1 & 0.428 & 0.079 & 0.007 & 1.610 & 10 \\
Bv2 & 0.420 & 0.072 & 0.006 & &
\end{tabular}

The bottom boundary condition was approximated by a constant pressure head. For lysimeters 3-4 and 9-10 (constant water level at $135 \mathrm{~cm}$ depth), a pressure head of $h=+15 \mathrm{~cm}$ and for lysimeters 1-2 and 11-12 (constant water level at $210 \mathrm{~cm}$ depth), a pressure head of $h=-60 \mathrm{~cm}$ was imposed at the bottom in $150 \mathrm{~cm}$ depth. Temperature boundary conditions were selected for the simulation of heat transport with measured soil surface temperature as upper and an assumed constant soil temperature of $5{ }^{\circ} \mathrm{C}$ in $150 \mathrm{~cm}$ depth as lower boundary conditions. Maximum rooting depth of grass was set at $50 \mathrm{~cm}$ (e.g., Wegehenkel and Gerke, 2013). For the simulation of root water uptake according to Eq. (2) and (3), the values of the parameters $h_{1}=-25 \mathrm{hPa} \approx 25.5 \mathrm{~cm}, h_{2}=-300 \mathrm{hPa} \approx 305 \mathrm{~cm}, h_{3}=-1000$ $\mathrm{hPa} \approx 1020 \mathrm{~cm}$ and $h_{4}=-8000 \mathrm{hPa} \approx 8158 \mathrm{~cm}$ for grass cover were taken from the Hydrus-1D data base (Simunek et al., 2008) and confirmed by others (e.g., Supit et al., 1994). A limitation for grass root water uptake was assumed for pressure heads $>-25 \mathrm{hPa}$ resulting from low oxygen in the soil root zone. A linear decrease of the vertical root distribution from soil surface down to the maximum rooting depth (i.e., function $b(x)$ in Eq. (4)) was assumed according to Feddes et al. (1978).

First set of the soil hydraulic parameters (Table 2) was obtained by fitting a curve to the pF-data in Table 1 using the program RETC (van Genuchten et al., 1991) and corresponding values of $K_{s a t}$ were obtained from tabular data for texture classes (AG Boden, 2005). In this procedure, the values of $\theta_{s}$ were set equal to the maximum of measured soil water contents (i.e., the porosity in Table 1).
Second set of the soil hydraulic parameters and saturated hydraulic conductivity (Table 3 ) was generated by using the neural network pedotransfer function of the ROSETTA program (Schaap et al., 2001) as implemented in Hydrus-1D and the measured contents of clay, silt, and sand (Table 1).

As the initial condition for the unsaturated upper parts of the lysimeter soils, the water content at field capacity (i.e., $\mathrm{pF}=1.8$, $h=-63 \mathrm{~cm}$ ) calculated from the water retention functions in Table 2 was assumed. For lysimeters 3-4 and 9-10 with a water table at $135 \mathrm{~cm}$ depth, initial soil water contents below the water table were set to $\theta_{s}$ (Table 2). The two soil hydraulic data sets (Tables 2 and 3 ) were then used; each of the two lysimeter pairs (i.e., 1-2, 3-4, 9-10, 11-12) was treated as a single simulation scenario (Tables 1 and 2).

\section{Analysis of model performance}

We compared simulated rates of ETa, changes in soil water storage, and drainage rates with those obtained from the lysimeter measurements using the model efficiency coefficients NashSutcliffe (NS) (Nash and Sutcliffe, 1970) and index of agreement (IA) (Willmott, 1982) and as absolute error measure, the root-mean-square-error (RMSE) as:

$$
N S=1-\frac{\sum_{i=1}^{N}\left(\theta_{\text {sim }}-\theta_{\text {obs }}\right)^{2}}{\sum_{i=1}^{N}\left(\theta_{\text {obs }}-\theta_{\text {obs-mean }}\right)^{2}}
$$




$$
\begin{aligned}
& I A=1-\frac{\sum_{i=1}^{N}\left(\theta_{\text {sim }}-\theta_{\text {obs }}\right)^{2}}{\sum_{i=1}^{N}\left[\left|\theta_{\text {sim }}-\theta_{\text {obs-mean }}\right|+\left|\theta_{\text {obs }}-\theta_{\text {obs-mean }}\right|\right]^{2}} \\
& R M S E=\sqrt{\frac{\sum_{i=1}^{N}\left(\theta_{\text {sim }}-\theta_{\text {obs }}\right)^{2}}{N}}
\end{aligned}
$$

where $\theta_{\text {sim }}$ and $\theta_{\text {obs }}$ are the simulated and measured values; $N$ means here the number of data pairs for the investigated time period, whilst $\theta_{\text {obs-mean }}$ and $\theta_{\text {sim-mean }}$ present the corresponding mean values. The Nash-Sutcliffe-Index $N S$ ranges between $-\infty$ and 1 and $I A$ from 0 to 1 ; a value of 1 of $N S$ or $I A$ indicates a perfect match of simulated to observed values.

\section{RESULTS AND DISCUSSION \\ Soil temperatures and snow cover}

Simulated and measured soil temperatures at $10 \mathrm{~cm}, 20 \mathrm{~cm}$, and $30 \mathrm{~cm}$ depths are shown in Figure 2. The periods with soil freezing (i.e., January-March 1996) and the following frost-free periods (winter periods 1996/1997 and 1997/1998) could be described, based on default parameter values of thermal conductivity and an assumed constant soil temperature at the lower boundary.

Only for the period January - March 1996, a longer period of a significant snow cover up to a height of $30 \mathrm{~mm}$ water equivalent was predicted (Fig. 2). In all other winter periods, only small amounts of snow were calculated by the model according to observed weather data.

\section{Simulation of water flow in the sand lysimeters (1-4)}

At the lysimeters 1-2 with lower water table, measured and simulated cumulative outflow using the first set of soil hydraulic parameters (Table 2a) were in the same order of magnitude between -600 and $-622 \mathrm{~mm}$ (Fig. 3, second graph); the highest value of cumulative outflow (i.e., $-700 \mathrm{~mm}$, lysi- meter 2) was calculated by using the second set of soil hydraulic parameters.

Daily drainage rates and cumulative changes in soil water storage were simulated adequately by using both sets of the soil hydraulic parameters (Tables $2 \mathrm{a}$ and $3 \mathrm{a}$ ) suggested by a model performance with an $I A$ from 0.90 to 0.92 and $N S$ of 0.60 to 0.62 for drainage and $I A$ from 0.83 to 0.94 and $N S$ from 0.50 to 0.78 for soil water storage (Figs. 4-6, Table 4).

In the graphical presentation of measured and simulated daily outflow and cumulative changes of soil water storage, we focused on the summer period 1996 with the two highest daily precipitation rates of $56 \mathrm{~mm} \mathrm{~d}^{-1}$, observed on May 3, 1996 and $41 \mathrm{~mm} \mathrm{~d}^{-1}$ measured on August 14, 1996 (Fig. 4). In addition, periods from February to August 1997 with high rainfall of $46 \mathrm{~mm} \mathrm{~d}^{-1}$, observed on July 20, 1997 and from June-December 1998 including a period of high lysimeter outflow from October 25, 1998 to November 20, 1998 (Figs. 5-6) were analysed in more detail.

In April-May 1996, simulated cumulative soil water storage changes at the lysimeters 1-2 were below the measured values (Fig. 4). This was mainly due to gaps in the observations of lysimeter weight changes in January and February 1996.

The lower model performance for the lysimeter 2 for soil water storage was mainly due to a measurement error at July, 21, 1997 (Fig. 5, second graph). In contrast to the lysimeter 1, soil water storage in lysimeter 2 showed no increase at this day despite previous high rainfall (Fig. 5, first and second graphs). This was caused by a mechanical problem in the weighing system of lysimeter 2 at this day.

Cumulative ETa simulated by using the second set of soil hydraulic parameters was lower than that calculated by using the first set of soil hydraulic parameters mainly due to the corresponding simulated higher outflow (Fig. 3, first and second graphs). Model performance for daily ETa-rates at the lysimeters 1-2 with an $I A$ from 0.90 to 0.91 and $N S$ between 0.60 and 0.65 , was higher for the model calculations using the first set of soil hydraulic parameters (Table 2a) than those using the second set (Table 3a) suggested by an $I A$ from 0.88 to 0.89 and $N S$ from 0.54 to 0.56 (Table 4 ).



Fig. 2. Simulated snow cover (mm) and simulated and measured soil temperatures (Soil temp.) in ${ }^{0} \mathrm{C}$ at $10 \mathrm{~cm}, 20 \mathrm{~cm}$ and $30 \mathrm{~cm}$ depth. 

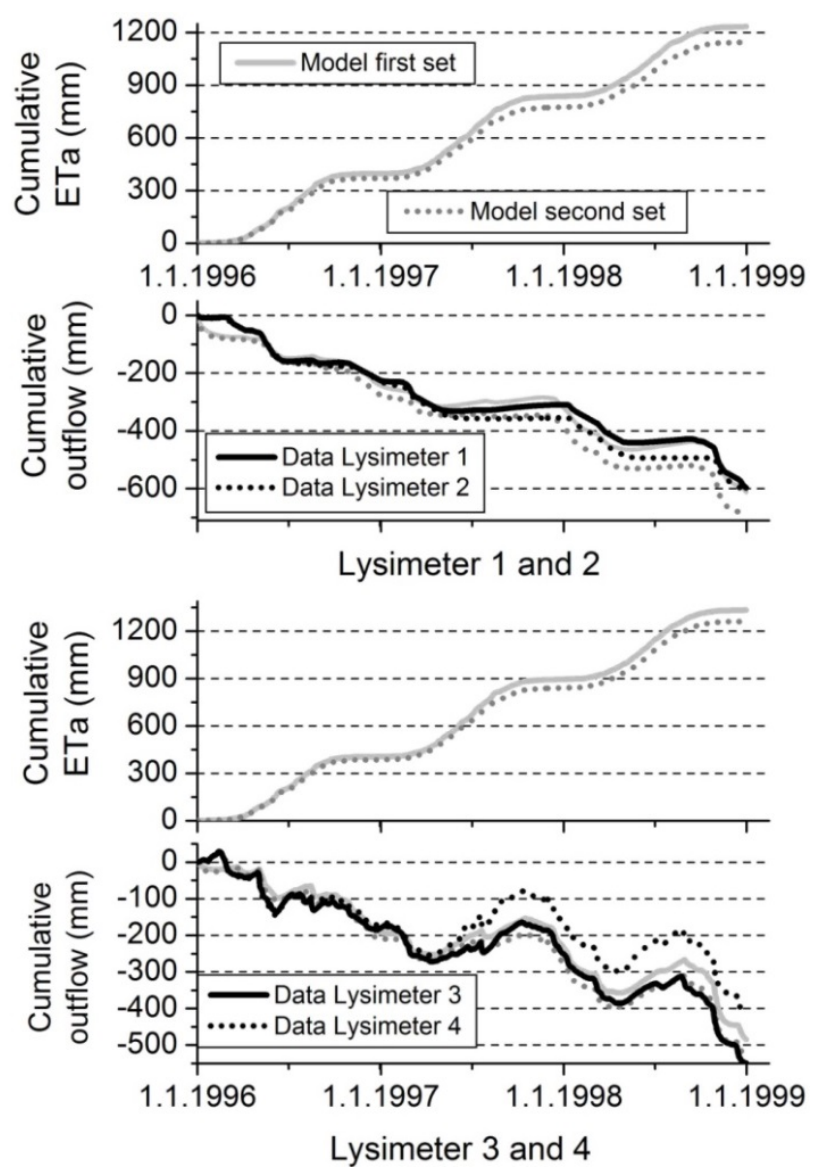

Fig. 3. Simulated cumulative actual evapotranspiration (ETa), measured (Data Lysimeter 1-Lysimeter 4) and simulated cumulative outflow in mm using first (Model first set) and second (Model second set) set of soil hydraulic parameters (Table 2a, 3a), Lysimeter 1-2 (first and second graph), Lysimeter 3-4 (third and fourth graph).

The observed cumulative outflow value over the three-years period was $-409 \mathrm{~mm}$ for lysimeter 3 and $-550 \mathrm{~mm}$ for lysimeter 4 (Fig. 3, fourth graph). Observed capillary rise, indicated by a reverse trend in cumulative percolation (Fig. 3, fourth graph), was higher for lysimeter 4 than for lysimeter 3. Cumulative outflow calculated by using both sets of soil hydraulic parameters was similar and in the range of observed outflow from lysimeter 3 . In contrast to lysimeter 1-2, high outflow peaks on May, 4, 1996 with values of -25 to $-28 \mathrm{~mm} \mathrm{~d}^{-1}$ following the rainfall of $56 \mathrm{~mm} \mathrm{~d}^{-1}$ on May, 3, 1996, were observed at the lysimeters 3-4 (Fig. 4). These peaks were not well-captured in the simulations based on both sets of soil hydraulic parameters (Fig. 4). Therefore, $I A$ for bottom flux ranged only from 0.71 up to $0.83, N S$-values were between 0.31 and 0.50 , and $R M S E$ values from 1.4 to $1.9 \mathrm{~mm} \mathrm{~d}^{-1}$, indicating a lower model performance (Table 4). However, other measured outflow peaks at the lysimeters 3-4 such as the peaks on July 21, 1997 (Fig. 5) and on October 20, 1998 (Fig. 6) were simulated more adequately. Similar to lysimeter 1-2, cumulative ETa simulated by using the second set of soil hydraulic parameters was lower than that calculated by using the first set of soil hydraulic parameters (Fig. 3, third graph). This was also due to the corresponding higher outflow simulated by using the second set of soil hydraulic parameters. Model performance for daily ETa-rates at the lysimeters $3-4$ simulated by both sets of soil hydraulic parameters

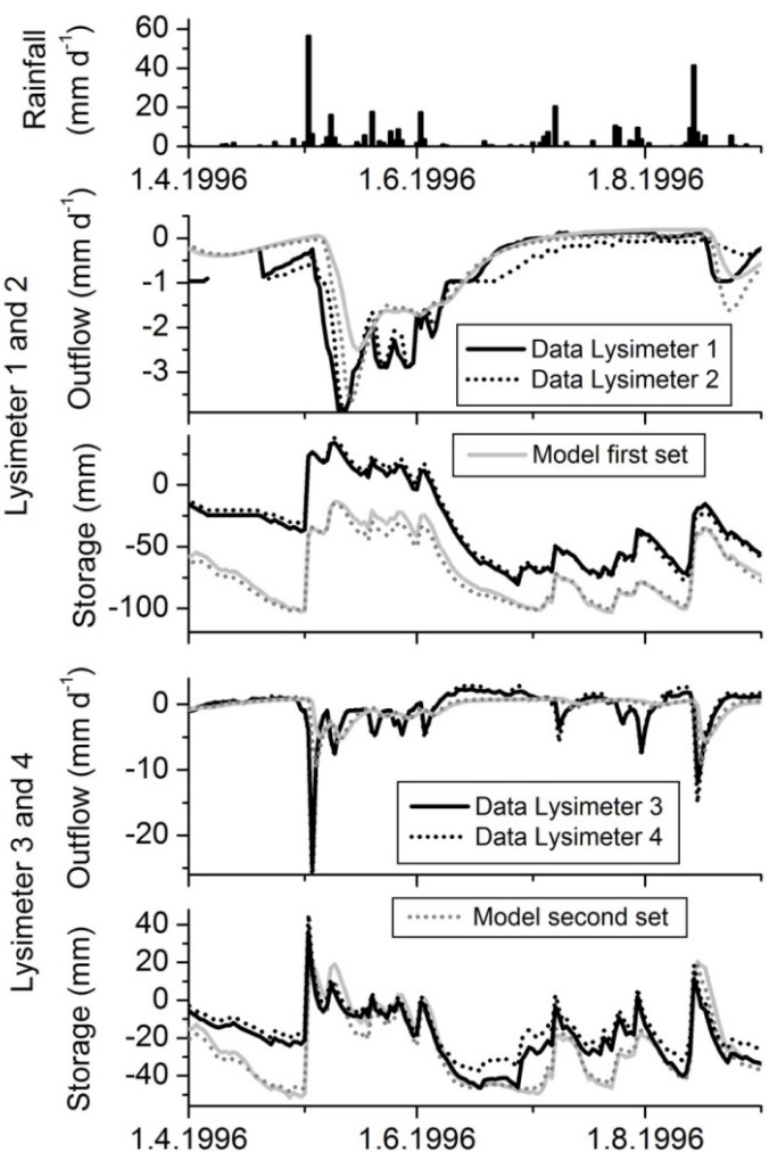

Fig. 4. Results for April-August 1996. Daily rainfall, and measured and simulated cumulative soil water storage change (storage) and outflow rates for lysimeters 1-2 (water table at $210 \mathrm{~cm}$ depth, first and second graphs) and 3-4 (water table at $135 \mathrm{~cm}$ depth, third and fourth graphs) using first (Model first set) and second (Model second set) sets of soil hydraulic parameters (Table 2a, 3a).

was described by an $I A$ form 0.85 to 0.90 and $N S$ from 0.52 to 0.60 (Table 4).

In other lysimeter studies (Herbst et al., 2005; Loos et al., 2007; Luo and Sophocleus, 2010), IA for outflow ranged between 0.67 and 0.98 , and $N S$-values were from -0.10 to 0.92 . Corresponding model performance for ETa in these studies showed an $I A$ from 0.93 to 0.99 and $N S$ from 0.41 to 0.96 (Herbst et al., 2005; Loos et al., 2007; Luo and Sophocleus, 2010). In comparison with these results, our model performance for outflow was in the upper range, but for ETa, it was only in the middle range of the model performances reported in the other studies (Table 4). In the previous lysimeter study by Wegehenkel and Gerke (2013), IA from 0.64 to 0.92 and NS from 0.32 to 0.71 were obtained for outflow at the lysimeters $1-4$ and corresponding model performance for ETa was described by an $I A$ from 0.87 to 0.91 and $N S$ ranging from 0.55 to 0.62 .

\section{Simulation of water flow in the silty-clay lysimeters (9-12)}

At the lysimeters 9-10 with higher water table, observed cumulative outflow values between $-412 \mathrm{~mm}$ and $-423 \mathrm{~mm}$ were in the same order of magnitude as those simulated by using the first set of soil hydraulic parameters (Table 2b; Fig. 7, second graph). In contrast, cumulative outflow calculated by using the second set of soil hydraulic parameters (Table $3 \mathrm{~b}$ ) showed 

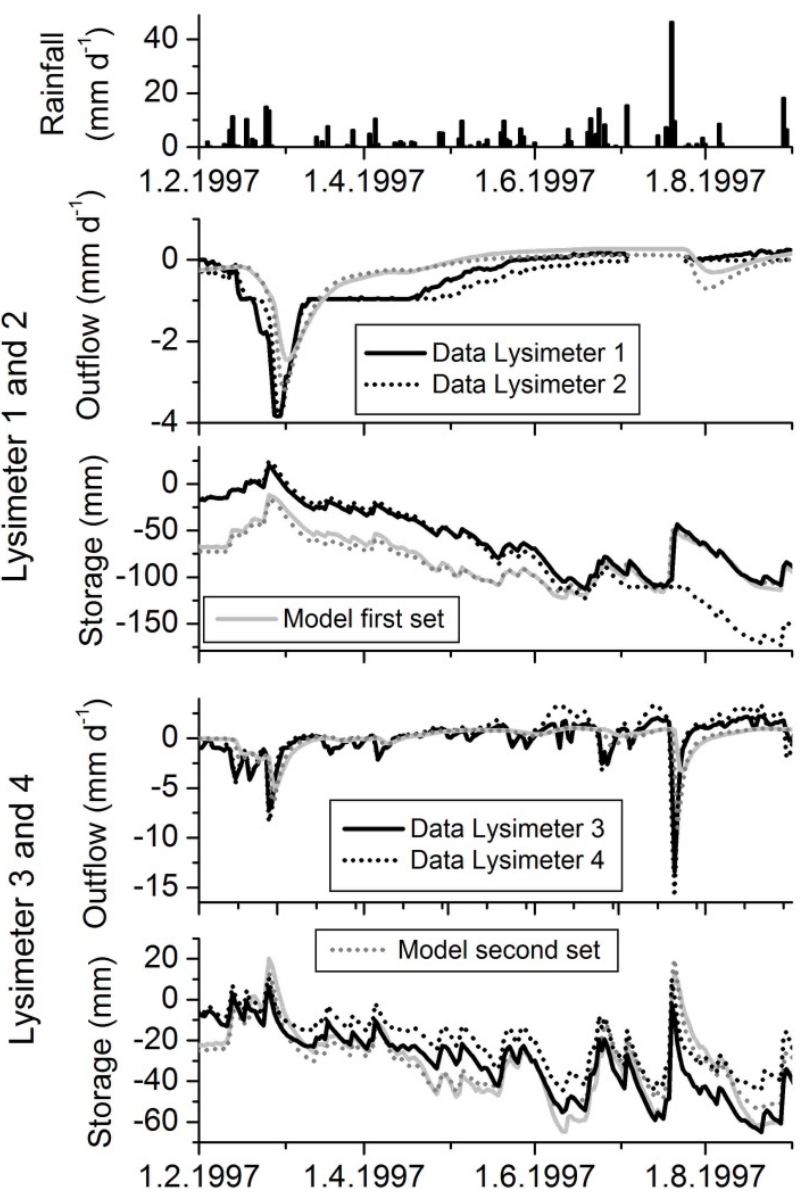

Fig. 5. Results for February-August 1997. Daily rainfall, and measured and simulated cumulative soil water storage change (storage) and outflow rates for lysimeters 1-2 (water table at $210 \mathrm{~cm}$ depth, first and second graphs) and 3-4 (water table at $135 \mathrm{~cm}$ depth, third and fourth graphs) using first (Model first set) and second (Model second set) sets of soil hydraulic parameters (Table 2a, 3a).

a distinct overestimation of capillary rise (reverse trend of cumulative outflow curve) in comparison with the other cumulative outflow curves (Fig. 7, second graph).

At the lysimeters 11-12 with the lower water table, measured cumulative outflow value was $-422 \mathrm{~mm}$ for lysimeter 11 and $-527 \mathrm{~mm}$ for lysimeter 12 over the three years period, while cumulative outflow simulated by using the first set of soil hydraulic parameters (Table $2 b$ ) run similar to that observed at the lysimeter 12 (Fig. 7, fourth graph). Similar to the lysimeters 910 , cumulative outflow simulated by using the second set of soil hydraulic parameters showed a distinct overestimation of capillary rise at the lysimeters 11-12 in comparison with the other cumulative outflow curves (Fig. 7, fourth graph).

Outflow peaks up to $-15 \mathrm{~mm} \mathrm{~d}^{-1}$ observed e.g. on May, 4, 1996 at the lysimeters $9-12$ were not simulated by using the first set of soil hydraulic parameters (Fig. 8). However, other measured high outflow peaks at the lysimeters 9-12 such as that on February 26, 1997 (Fig. 9) and that on October 28, 1998 (Fig. 10) were simulated more adequately.

Thus, model performance for outflow at the lysimeters 9-12 was described by an $I A$ from 0.82 to 0.86 and $N S$ from 0.52 to 0.54 (Table 5a). This model performance was still in the range reported from other studies (Herbst et al., 2005; Luo and Sophocleus, 2010; Loos et al., 2007) and higher than that repor-

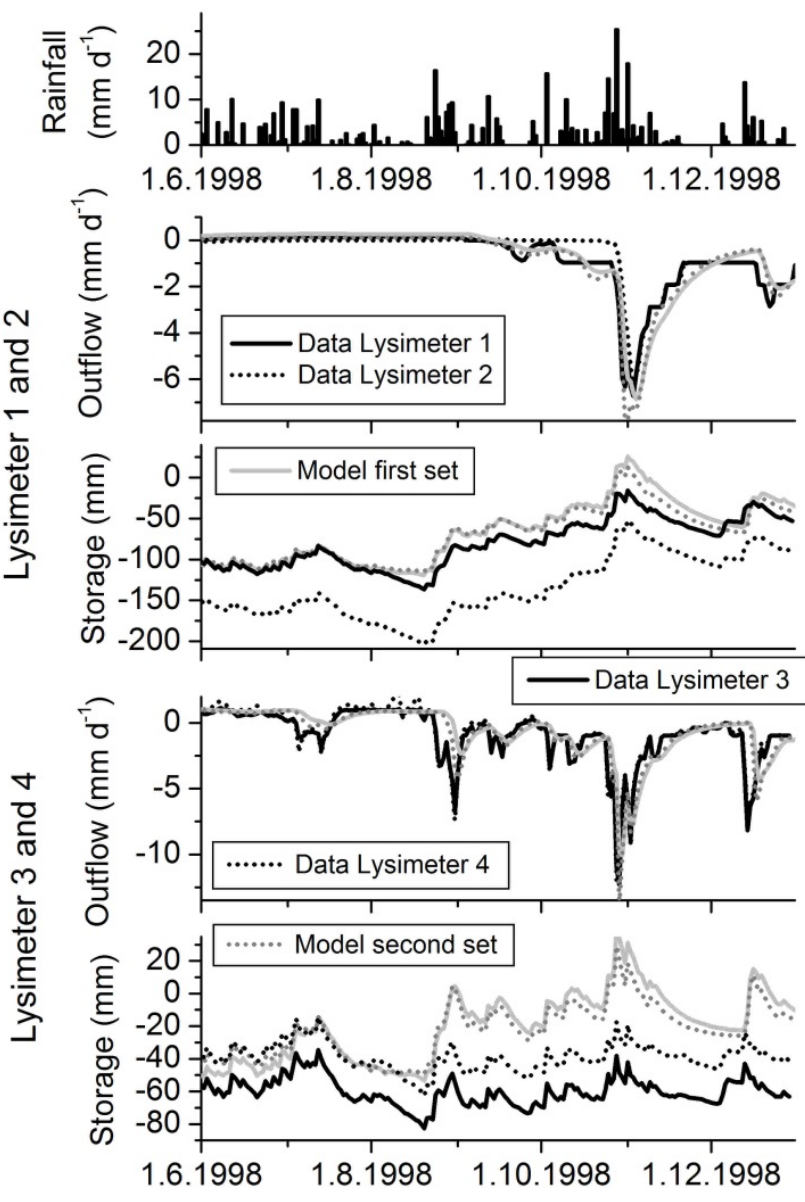

Fig. 6. Results for June-December 1998. Daily rainfall, and measured and simulated cumulative soil water storage change (storage) and outflow rates for lysimeters 1-2 (water table at $210 \mathrm{~cm}$ depth, first and second graphs) and 3-4 (water table at $135 \mathrm{~cm}$ depth, third and fourth graphs) using first (Model first set) and second (Model second set) sets of soil hydraulic parameters (Table 2a, 3a).

ted previously (Wegehenkel and Gerke, 2013) with an $I A$ from 0.48 to 0.77 and $N S$ between -0.37 and 0.15 . In contrast, daily drainage rates simulated by using the second set of soil hydraulic parameters were mainly overestimated and a large amount of simulated outflow peaks were not confirmed by the experimental data obtained from the lysimeters 9-12 (Fig. 8-10). Therefore, a low simulation performance for daily drainage was obtained when using these second set of soil hydraulic parameters (Table $3 \mathrm{~b}$ ) with an $I A$ from 0.54 to $0.67, N S$-values between -3.1 and -0.5 and RMSE from 1.5 to $2.3 \mathrm{~mm} \mathrm{~d}^{-1}$ (Table $5 \mathrm{~b}$ ).

Due to the higher capillary rise simulated by using the second set of soil hydraulic parameters, the calculated cumulative ETa ranged above that calculated by using the first set of soil hydraulic parameters (Fig. 7, first and third graph). Model performance of daily ETa simulated by using the first set of soil hydraulic parameters showed the best model performance in the study with an $I A$ from 0.92 to $0.94, N S$ from 0.72 to 0.75 and $R M S E$ of $0.6 \mathrm{~mm} \mathrm{~d}^{-1}$ (Table 5a). In the previous study of Wegehenkel and Gerke (2013), model performance for ETa at the lysimeters 9-12 was lower (IA from 0.87 to $0.91, N S$ within 0.55 and 0.66 ). In contrast, the model performance for daily ETa-rates calculated by using the second set of soil hydraulic parameters was lower indicated by an $I A$ from 0.87 to 0.90 and $N S$ from 0.35 to 0.53 (Table $5 \mathrm{~b}$ ). 
Water table effects on measured and simulated fluxes in weighing lysimeters for differently-textured soils

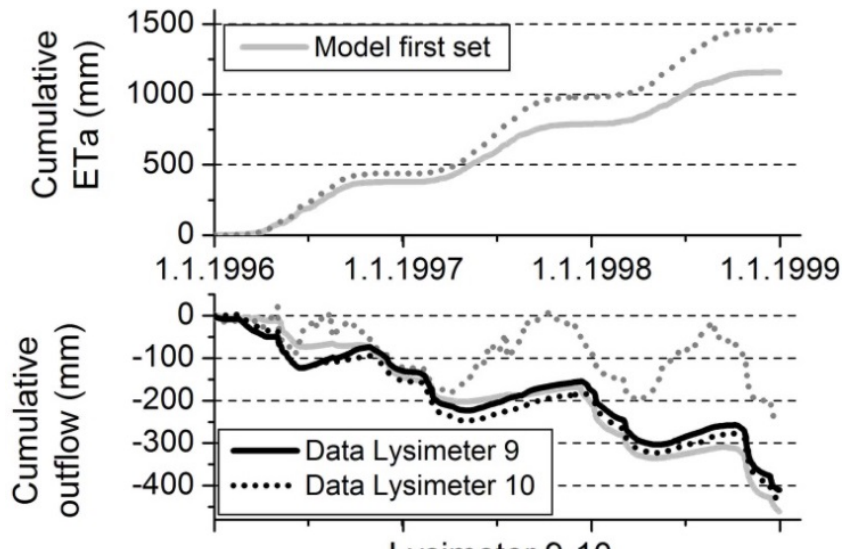

Lysimeter 9-10
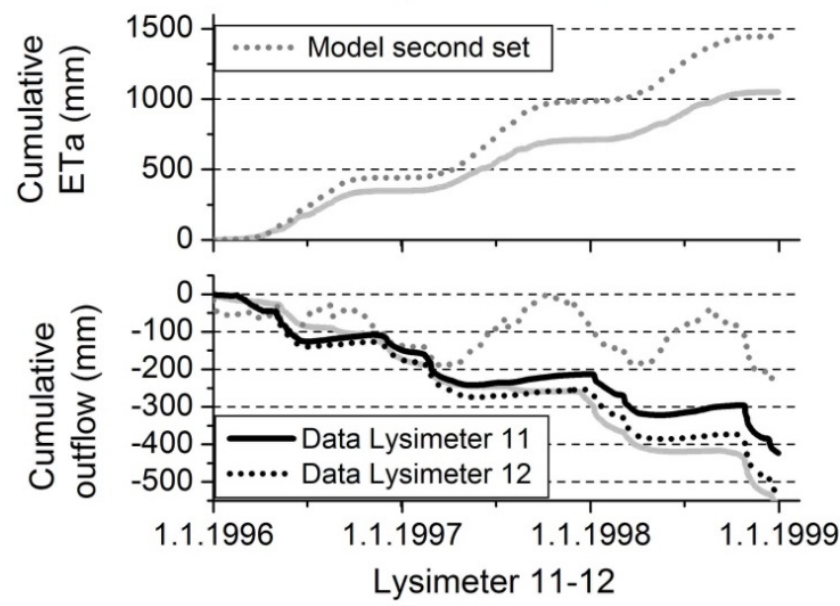

Fig. 7. Simulated cumulative actual evapotranspiration (ETa), measured (Lysimeter 9-Lysimeter 12) and simulated cumulative outflow in mm using first (Model first set) and second (Model second set) sets of soil hydraulic parameters (Table 2a, 3a), Lysimeter 9-10 (first and second graphs), Lysimeter 11-12 (third and fourth graphs).

\section{Impact of the water table depth on measured and simulated drainage}

Outflow rates of up to $-28 \mathrm{~mm} \mathrm{~d}^{-1}$ observed at the lysimeters 3-4 at e.g. May 4, 1996 were generally higher than those measured at lysimeters 1-2 with rates up to $-4 \mathrm{~mm} \mathrm{~d}^{-1}$ (Fig. 4-6). The lower water table at $210 \mathrm{~cm}$ depth resulted in unsaturated conditions at the bottom of lysimeters 1-2, while the higher water table at $135 \mathrm{~cm}$ depth led to constant saturated soil conditions at the bottom of lysimeters 3-4. Thus, the hydraulic conductivity values were generally lower at the bottom of lysimeters $1-2$ in contrast to those of lysimeters $3-4$ where the daily outflow rates were also larger (Fig. 4-6). These higher water tables led also to higher measured and simulated capillary rise and smaller soil water storage changes in lysimeters 3-4 than in lysimeters 1-2 (Figs. 3-6). ). A similar, but lower impact of the lower boundary condition was observed for the silty-clay lysimeters 9-12 (Figs. 7-10). Capillary rise at the lysimeters 9-10 with high water table was higher than at the lysimeters 11-12 with lower water table. Similarly, the outflow peaks e.g. observed on May 4, 1996 were higher $\left(-13\right.$ and $\left.-15 \mathrm{~mm} \mathrm{~d}^{-1}\right)$ for lysimeters 9-10 than for lysimeters 11-12 ( -9 and $-12 \mathrm{~mm} \mathrm{~d}^{-1}$ ) (Figs. 8-10). Such impacts of the conditions at the lower boundary on lysimeter outflow have been reported elsewhere (e.g., Abdou and Flury, 2004; Kasteel et al., 2007).

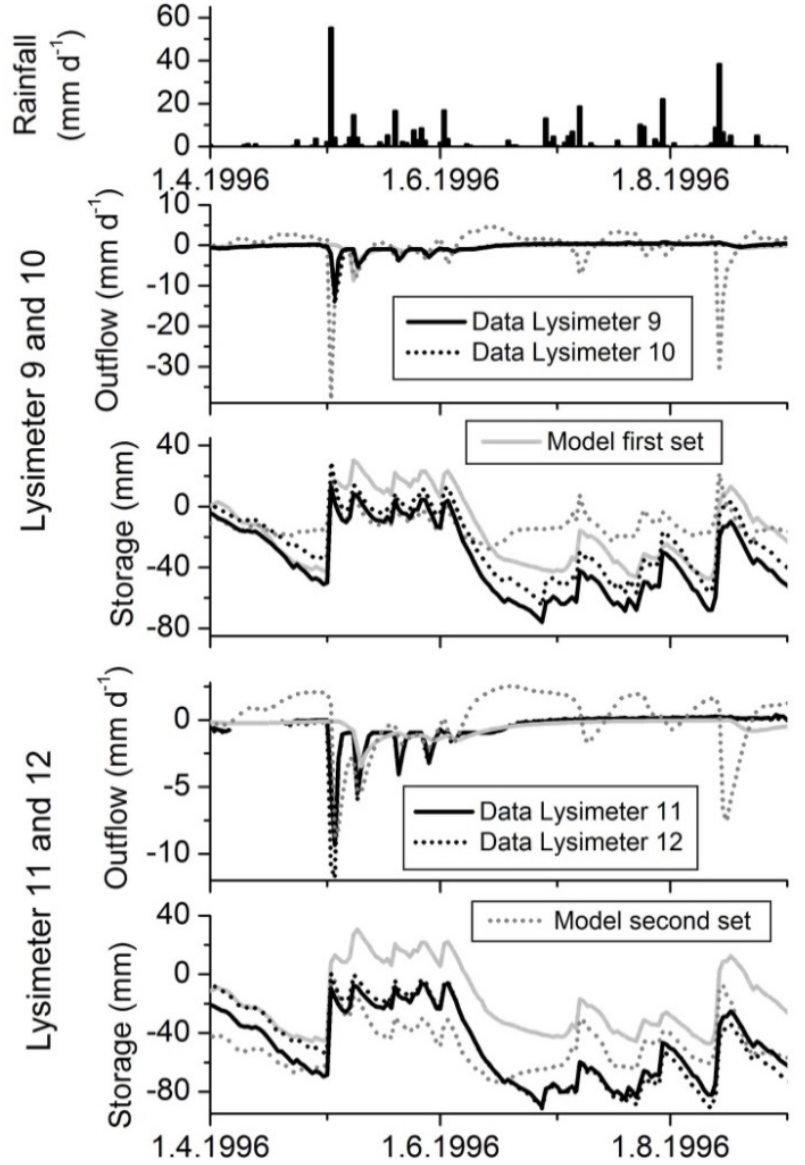

Fig. 8. Results for April-August 1996. Daily rainfall, and measured and simulated cumulative soil water storage change (storage) and outflow rates for lysimeters 9-10 (water table at $135 \mathrm{~cm}$ depth, first and second graphs) and 11-12 (water table at $210 \mathrm{~cm}$ depth, third and fourth graphs) using first (Model first set) and second (Model second set) sets of soil hydraulic parameters (Table $2 b, 3 b$ ).

However, the present results showed characteristic differences in the water flow simulations between sandy and siltyclay soils. At the sand lysimeters 1-4, cumulative bottom flux and outflow peaks were simulated adequately (Figs. 3-6) except for the high outflow peaks observed at the lysimeters 3-4 on May 4, 1996) (Fig. 4, third graph). This mismatch may be explained by differences between measured and simulated cumulative changes in soil water storage in April-May 1996 (Fig. 4, fourth graph) by ETa-induced soil water storage depletion. Due to the smaller soil moisture content, a larger amount of rainfall (May 3, 1996) could be stored than indicated by data from lysimeter 3-4 which led to reduced simulated outflow (Fig. 4, third and fourth graphs).

The percolation events measured at May, 4, 1996 in the lysimeters 9-12 were not simulated adequately by using the first set of soil hydraulic parameters (Fig. 8), despite a sufficient simulation of cumulative outflow (Fig. 7). However, measured and simulated cumulative change of soil water storage by using the first set of soil hydraulic parameters run mainly similar in April-May 1996 (Fig. 8). Since the other observed outflow peaks were simulated adequately by using the first set of soil hydraulic parameters (Fig. 9-10), we assume that the mismatch in in May 1996 in the lysimeters 9-12 (Fig. 8) may be explained by the occurrence of preferential flow. Neglecting the possibility of gaps between the lysimeter walls and the soil monoliths, 


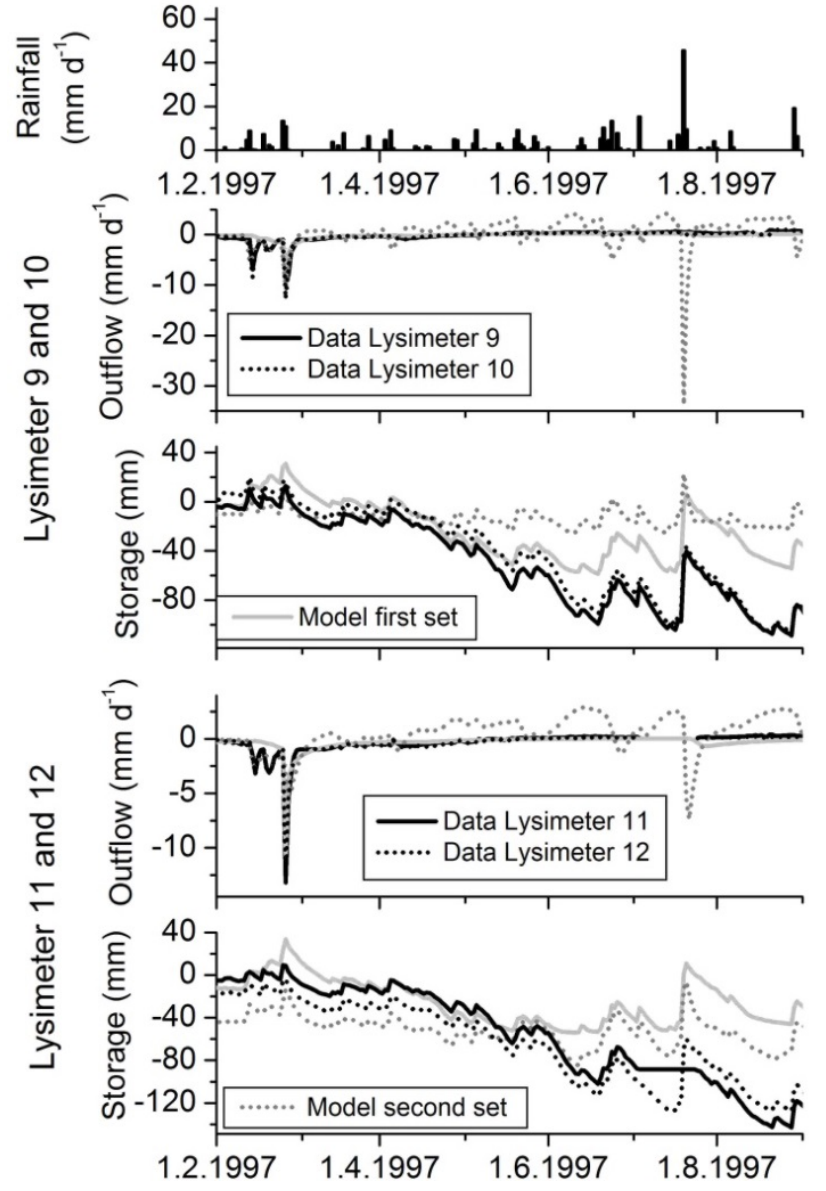

Fig. 9. Results for February-August 1997. Daily rainfall, and measured and simulated cumulative soil water storage change (storage) and outflow rates for lysimeters 9-10 (water table at $135 \mathrm{~cm}$ depth, first and second graphs) and 11-12 (water table at $210 \mathrm{~cm}$ depth, third and fourth graphs) using first (Model first set) and second (Model second set) sets of soil hydraulic parameters (Table 2b, 3b).
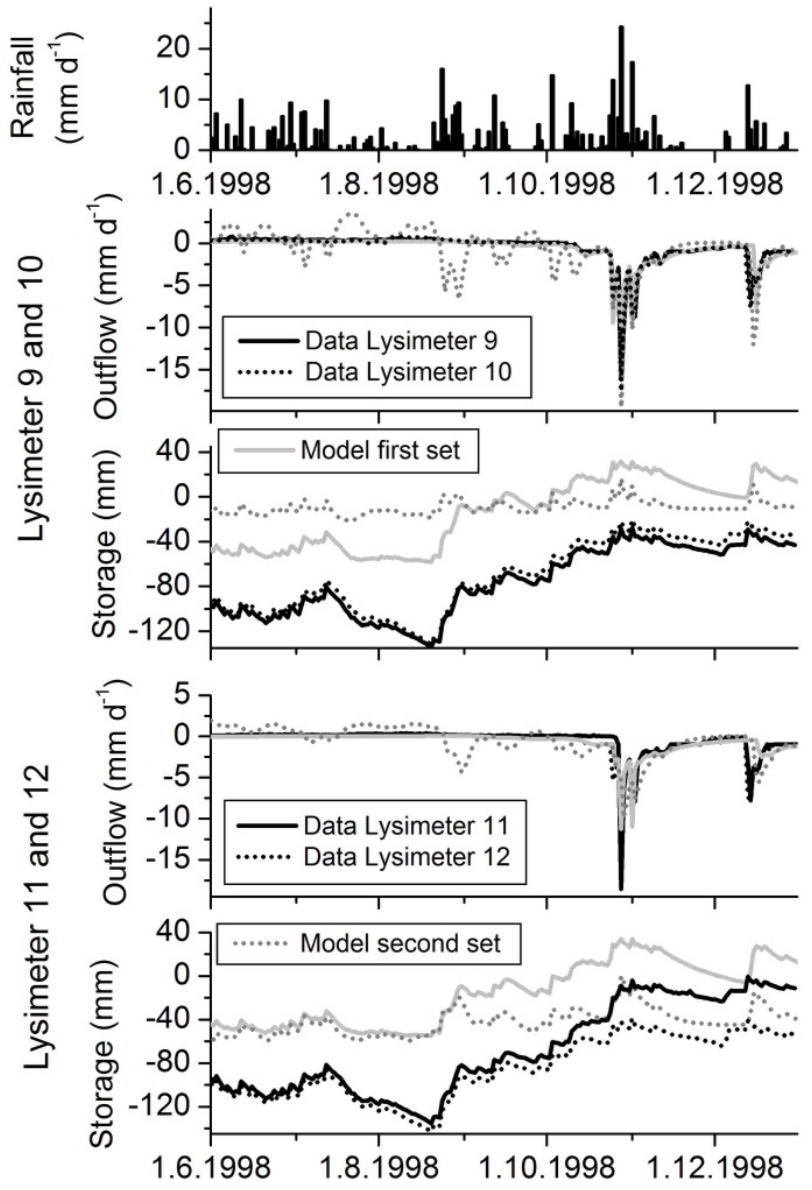

Fig. 10. Results for June-December 1998. Daily rainfall, and measured and simulated cumulative soil water storage change (storage) and outflow rates for lysimeters 9-10 (water table at $135 \mathrm{~cm}$ depth, first and second graphs) and 11-12 (water table at $210 \mathrm{~cm}$ depth, third and fourth graphs) using first (Model first set) and second (Model second set) sets of soil hydraulic parameters (Table 2b, 3b).

Table 4. Values of the model performance indices $I A, N S$, and RMSE ( $\left.\mathrm{mm} \mathrm{d}^{-1}\right)$, lysimeters 1-4, Berlin-Dahlem, $1996-1998$.

\begin{tabular}{|c|c|c|c|c|c|c|c|c|c|}
\hline \multicolumn{10}{|c|}{ a) Simulations using first set of soil hydraulic parameters (Table 2a) } \\
\hline \multirow[b]{2}{*}{ Lysimeter } & \multicolumn{3}{|c|}{ Outflow } & \multicolumn{3}{|c|}{ Daily changes in soil water storage } & \multicolumn{3}{|c|}{ Actual evapotranspiration } \\
\hline & $I A$ & NS & RMSE & $I A$ & $N S$ & $R M S E$ & $I A$ & NS & RMSE \\
\hline 1 & 0.92 & 0.62 & 0.6 & 0.94 & 0.78 & 1.9 & 0.91 & 0.65 & 0.5 \\
\hline 2 & 0.90 & 0.61 & 0.5 & 0.83 & 0.50 & 2.0 & 0.90 & 0.60 & 0.8 \\
\hline 3 & 0.75 & 0.45 & 1.5 & 0.91 & 0.64 & 2.2 & 0.89 & 0.60 & 0.8 \\
\hline 4 & 0.71 & 0.31 & 1.9 & 0.90 & 0.62 & 2.4 & 0.87 & 0.58 & 0.8 \\
\hline \multicolumn{10}{|c|}{ b) Simulations using second set of soil hydraulic parameters (Table 3a) } \\
\hline 1 & 0.90 & 0.60 & 0.5 & 0.94 & 0.77 & 1.9 & 0.89 & 0.56 & 0.8 \\
\hline 2 & 0.90 & 0.60 & 0.6 & 0.83 & 0.50 & 2.8 & 0.88 & 0.54 & 0.8 \\
\hline 3 & 0.83 & 0.50 & 1.4 & 0.92 & 0.67 & 2.3 & 0.90 & 0.60 & 0.8 \\
\hline 4 & 0.76 & 0.43 & 1.9 & 0.91 & 0.65 & 2.4 & 0.85 & 0.52 & 0.9 \\
\hline
\end{tabular}

activation of preferential flow paths within the silty-clay soils in the lysimeters could perhaps be caused by soil shrinkage due to longer drying periods. From January 1, 1996 until May 2, 1996, precipitation of $59 \mathrm{~mm}$ was measured while an ETa of $94 \mathrm{~mm}$ at the lysimeters 9-12 was calculated for that period. This rainfall corresponded to only $11 \%$ of the annual rate of precipitation at $534 \mathrm{~mm}$ observed in 1996 and indicated a relatively dry period (Fig. 11). 


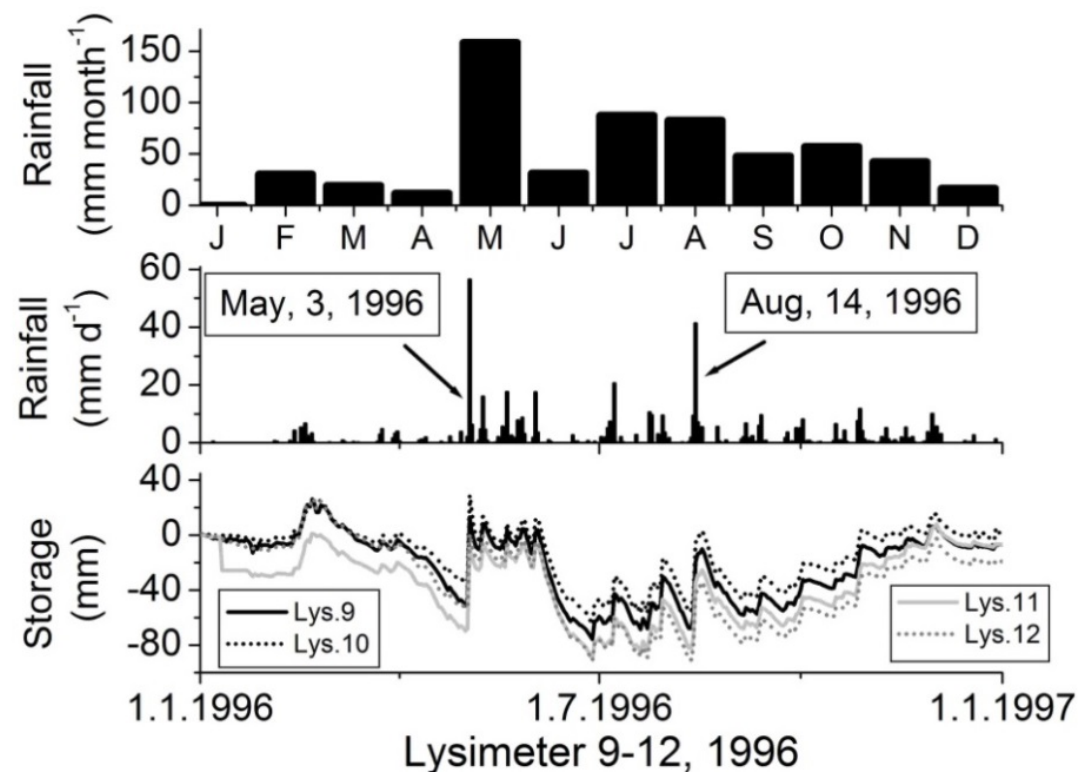

Fig. 11. Monthly rainfall $\left(\mathrm{mm} \mathrm{month}^{-1}\right)$, daily rainfall in $\mathrm{mm} \mathrm{d}^{-1}$ and measured cumulative changes in soil water in mm (storage), lysimeter 9-12, 1996.

Table 5. Values of the model performance indices IA, NS, and RMSE ( $\left.\mathrm{mm} \mathrm{d}^{-1}\right)$, lysimeters 9-12, Berlin-Dahlem, $1996-1998$.

a) Simulations using first set of soil hydraulic parameters (Table 2b)

\begin{tabular}{l|lll|lll|lll}
\hline & Outflow & & \multicolumn{3}{l|}{ Daily changes in soil water storage } & \multicolumn{2}{l}{ Actual evapotranspiration } \\
\hline Lysimeter & $I A$ & $N S$ & $R M S E$ & $I A$ & $N S$ & $R M S E$ & $I A$ & $N S$ & $R M S E$ \\
\hline 9 & 0.86 & 0.54 & 0.9 & 0.94 & 0.81 & 1.9 & 0.94 & 0.75 & 0.6 \\
10 & 0.84 & 0.53 & 1.0 & 0.94 & 0.82 & 2.1 & 0.93 & 0.74 & 0.6 \\
11 & 0.82 & 0.52 & 0.9 & 0.93 & 0.80 & 1.8 & 0.93 & 0.74 & 0.6 \\
12 & 0.82 & 0.52 & 0.9 & 0.91 & 0.75 & 2.1 & 0.92 & 0.72 & 0.6 \\
\hline \multicolumn{7}{l}{ b) Simulations } \\
\hline 9 & 0.5 using second set of soil hydraulic parameters (Table 3b) & -3.1 & 2.3 & 0.89 & 0.67 & 2.0 & 0.87 & 0.36 & 0.9 \\
10 & 0.64 & -2.8 & 2.3 & 0.89 & 0.66 & 2.1 & 0.87 & 0.35 & 0.9 \\
11 & 0.62 & -0.7 & 1.5 & 0.92 & 0.69 & 1.7 & 0.90 & 0.53 & 0.8 \\
12 & 0.67 & -0.5 & 1.6 & 0.90 & 0.62 & 1.8 & 0.88 & 0.43 & 0.9 \\
\hline
\end{tabular}

During this 4-month dry period, measured changes in the soil water storage decreased especially shortly before May, 3, 1996 in the lysimeters 9-12 (Figs. 8 and 11). From May to August, 1996, the precipitation was $361 \mathrm{~mm}$ or $68 \%$ of the annual rate for 1996. Indications for the development of preferential flow paths in the lysimeters 9-12 in April-May 1996 might be hypothesized from the discrepancy between the rapid outflow rate of up to $14 \mathrm{~mm} \mathrm{~d}^{-1}$ observed on May 4, 1996 following a rainfall of $56 \mathrm{~mm} \mathrm{~d}^{-1}$ on May 3, 1996 with previous dry soil, and a zero outflow rate observed August 14, 1996 following a similar rain event of $41 \mathrm{~mm} \mathrm{~d}^{-1}$ with previous higher soil moisture (Figs. 8 and 11).

\section{CONCLUSIONS}

The location of the water table as bottom boundary condition had a strong impact on observed lysimeter outflow rates. The different water levels created differences in capillary rise.

For the sand lysimeters, the model performance was sufficient using both sets of soil hydraulic parameters and the impact of the lower boundary on lysimeter water balance could be simulated except for a shorter period at the beginning of the simulation period.

For the silty-clay lysimeters, only the simulations using the first set of soil hydraulic parameters sufficiently described the lysimeter water balance. At the higher water table and near the lysimeter bottom, the soil moisture status was limited to a relatively small range of higher water contents. For such conditions, soil hydraulic parameters obtained from soil core data seem better than those using a pedotransfer function. The lower model performance as compared to the sand lysimeters in terms of $I A$ and Nash-Sutcliffe was mainly caused by a few drainage peaks that could not be described with the Richards equation due to assumed preferential flow in the macropores of the silty-clay soil in April-May 1996.

Further improvements in the model application and parameterization require distributed soil moisture data; the adequate description of fast drainage events requires a preferential flow model and higher temporal resolution of infiltration rates. 
Acknowledgements. This study was financially supported by the German Federal Ministry of Consumer Protection, Food and Agriculture and the Ministry of Agriculture, Environmental Protection and Regional Planning of the Federal State of Brandenburg (Germany). Thanks to Th. Zenker and H. Diestel, Department of Applied Hydrology, Resource Protection, Irrigation, and Drainage of the Technical University of Berlin, Germany for providing the lysimeter data set.

\section{REFERENCES}

Abdou, H.M., Flury, M.,2004. Simulation of water flow and solute transport in free drainage lysimeters and field soils with heterogeneous structures. European Journal of Soil Science, 55, 229-241.

AG Boden, 2005. Bodenkundliche Kartieranleitung. Bundesanstalt für Geowissenschaften und Rohstoffe und den Geologischen Landesämtern in der Bundesrepublik Deutschland. [Manual of soil mapping]. 5 Ed. Hannover, 438 p.

Corwin, D.L., 2000. Evaluation of a simple lysimeter design modification to minimize sidewall flow. Journal of Contaminant Hydrology, 42, 35-49.

Chung, S.O., Horton, R., 1987. Soil heat and water flow with a partial surface mulch. Water Resources Research, 23, 2175 2186.

Diestel, H., Zenker, T., Schwartengraeber R., Schmidt M., 2007. The lysimeter station at Berlin-Dahlem. In: Kersebaum, K.C., Hecker, J.M., Mirschel, W., Wegehenkel, M., (Eds.): Modelling Water and Nutrient Dynamics in Soil Crop Systems. Springer, Dordrecht, pp. 259-267.

Durner, W., Janssen, U., Iden, S.C., 2008. Effective hydraulic properties of layered soils at the lysimeter scale determined by inverse modelling. European Journal of Soil Science, 59, $114-224$.

FAO - Unesco. 1988. Soil Map of the World. Food and Agriculture Organization of the United Nations, Rome, $119 \mathrm{p}$.

Feddes, R.A., Kowalik, P.J., Zaradny, H., 1978. Simulation of Field Water Use and Crop Yield. John Wiley and Sons, New York.

Herbst, M., Fialkiewicz, W., Chen, T., Pütz, T., Thiery, D., Mouvet, C., Vachaud, G., Vereecken, H., 2005. Intercomparison of flow and transport models applied to vertical drainage in cropped lysimeters. Vadose Zone Journal, 4, 240-254.

Kasteel, R., Pütz, T., Vereecken, H., 2007. An experimental and numerical study on flow and transport in a field soil using zero-tension lysimeters and suction plates. European Journal of Soil Science, 58, 632-645.

Kelleners, T.J., Soppe, W.O., Ayars, J.E., Simunek, J., Skaggs, T.H., 2005. Inverse analysis of upward water flow in a groundwater table lysimeter. Vadose Zone Journal, 4, 558572.

Loos, C., Gayler, S., Priesack, S., 2007. Assessment of water balance simulations for large scale weighing lysimeters. Journal of Hydrology, 335, 3-4, 259-270.

Luo, Y., Sophocleous, M., 2010. Seasonal groundwater contribution to crop-water use assessed with lysimeter observations and model simulations. Journal of Hydrology, 389, $325-335$.
Mertens, J., Barkle, G.F., Stenger, R., 2005a. Numerical analysis to investigate the effects of the design and installation of equilibrium tension plate lysimeters on leachate volume. Vadose Zone Journal, 4, 488-499.

Mertens, J., Madsen, H., Kristensen, M., Jaques, D., Feyen, J., $2005 \mathrm{~b}$. Sensitivity of soil parameters in unsaturated zone modelling and the relation between effective, laboratory and in-situ estimates. Hydrological Processes, 19, 1611-1633.

Mualem, Y., 1976. A new model for predicting the hydraulic conductivity of unsaturated porous media. Water Resources Research, 12, 3, 513-522.

Nash, J.E., Sutcliffe, J.V., 1970. River flow forecasting through conceptual models. Part 1: a discussion of principles. Journal of Hydrology, 10, 282-290.

Schaap, M.G., Leij, F.J., van Genuchten, M.Th., 2001. Rosetta: A computer program for estimating soil hydraulic parameters with hierarchical pedotransfer functions. Journal of Hydrology, 251, 163-176.

Schelle, H., Iden, S.C., Fank, J., Durner, W., 2012. Inverse estimation of soil hydraulic and root distribution parameters from lysimeter data. Vadose Zone Journal, doi: 10.2136/vzj2011.0169

Selle, B., Minasny, B., Bethune, M., Thayalakumaran, Th., Chandra S., 2011. Applicability of Richards' equation models to predict deep percolation under surface irrigation. Geoderma, 160, 569-578.

Simunek, J., Sejna, M., Saito, H., Sakai, M., van Genuchten, M., 2008. The Hydrus-1D-Software Package for simulating the one-dimensional movement of water, heat and multiple solutes in variably saturated media Version 4.0. Department of Environmental Sciences, University of California, Riverside, $281 \mathrm{p}$.

Supit, I., Hooijer, A.A., van Diepen, C.A., 1994. System Description of the Wofost 6.0 Crop Simulation Model Implemented in CGMS, Vol. 1: Theory and Algorithms. Joint Research Centre, Commission of the European Communities, EUR 15956 EN, Luxembourg, 146 p.

Unold, G.v., Fank, J., 2008. Modular design of field lysimeters for specific application needs. Water, Air and Soil Pollution: Focus, 8, 233-242.

van Genuchten, M.Th., 1980. A closed form equation for predicting the hydraulic conductivity of unsaturated soils. Soil Science Society of America Journal, 44, 892-898.

van Genuchten, M.Th., Leij, F.J., Yates, S.R., 1991. The RETC Code for Quantifying the Hydraulic Functions of Unsaturated Soils, Version 1.0. EPA Report 600/2-91/065. U.S. Salinity Laboratory, USDA, ARS, Riverside, California.

Wegehenkel, M., Zhang, Y., Zenker, T., Diestel, H., 2008. The use of lysimeter data for the test of two soil water balance models. A case study. Journal of Plant Nutrition and Soil Science, 171, 762-776.

Wegehenkel, M., Gerke, H.H., 2013. Comparison of ETa measured by weighing lysimeters with simulations based on the Penman formula and a crop growth model. Journal of Hydrology and Hydromechanics, 61, 2, 161-172.

Willmott, C.J., 1982. Some comments on the evaluation of model performance. Bulletin of American Meteorological Society, 64, 1309-1313. 